Ks. Józef Stala

PAT Kraków

\title{
IMPLIKACJE HISTORYCZNO-SPOŁECZNE DZIAŁALNOŚCI DUSZPASTERSKIEJ I KATECHETYCZ- NEJ KOŚCIOŁA W POLSCE I KOŚCIOŁA TARNOWSKIEGO W PIERWSZYCH LATACH PO II WOJNIE ŚWIATOWEJ
}

\section{THE HISTORICAL AND SOCIAL IMPLICATIONS OF PASTORAL AND CATECHETICAL WORK OF THE CHURCH IN POLAND AND THE CHURCH IN THE DIOCESE OF TARNÓW IN THE YEARS FOLLOWING WORLD WAR II}

After World War II was over, the political map of Europe changed radically, which affected Poland as well. The differences were not limited merely to the changes of the borders, but they also meant the changes of political and social systems: a new system was enforced upon Poland by the USSR. The Polish Catholic Church had to learn to function in the midst of those rapid changes, stripped of her possessions, persecuted and restrained in her actions. This article shows the pastoral and catechetical work of the Church in Poland and the Church in the diocese of Tarnów in the years following World War II, with an emphasis on the historical and social circumstances of those times.

Okres wolności, wielkich planów i zamierzeń II Rzeczypospolitej został szybko przerwany nadejściem II wojny światowej. Po klęsce wrześniowej Kościół pozostał monolitem, na którym można było się oprzeć. W tej sytuacji dziejowej jego zadaniem była również obrona polskiej tradycji narodowej, godności i praw wszystkich ludzi. Po zakończeniu II wojny światowej mapa Europy uległa wielkim zmianom. Dotknęły one również Polski. Wiązały się nie tylko ze zmianą granic państwa, ale również $\mathrm{z}$ nowym systemem polityczno-społecznym, jaki został naszemu krajowi narzucony przez Związek Radziecki. W wirze tych przemian swoje miejsce musiał odnaleźć również Kościół 
katolicki, pozbawiony swoich majątków i ograniczany w swych działaniach. Stąd też wydaje się słusznym podjęcie w niniejszym artykule zagadnienia działalności duszpasterskiej i katechetycznej Kościoła w Polsce i Kościoła w diecezji tarnowskiej w pierwszych latach po II wojnie światowej, wskazując na ówczesne implikacje historyczne i społeczne.

\section{Kościół w Polsce}

W pierwszych miesiącach powstawania Polski Ludowej władza ludowa obchodziła się z duchowieństwem katolickim bardzo ostrożnie. „Nie ma żadnych zakłóceń $\mathrm{w}$ publicznych nabożeństwach i księża nie są nękani” - czytamy w jednym z poufnych raportów ambasadora angielskiego w Moskwie, sporządzonym 23 kwietnia 1945 r. dla Stolicy Apostolskiej ${ }^{1}$. Autorytety kościelne, czytamy dalej w raporcie, „zachowują postawę całkowitej neutralności i nie pozwalają na to, by Kościół stał się punktem gromadzącym jakikolwiek ruch polityczny czy narodowy"2.

Wprawdzie hierarchia kościelna nie brała aktywnego udziału w życiu politycznym, ale nabrzmiałe problemy społeczne nie były jej obojętne. $\mathrm{Na}$ pierwszej powojennej Konferencji Episkopatu, odbytej po sześcioletniej przerwie, 26 i 27 czerwca 1945 r. na Jasnej Górze, biskupi i rządcy diecezji polskich „zastanawiali się nad stratami i szkodami, jakie zawierucha wojenna zadała życiu religijnemu i duchowieństwu na ziemiach polskich oraz nad sposobami usunięcia szkód”3. Szczególnie konferencja „wskazała na niebezpieczeństwa, jakie zagrażają świętości węzła małżeńskiego oraz wychowaniu przyszłych pokoleń i omawiano zgodnie z posłannictwem Kościoła środki, które doprowadzą do przywrócenia w narodzie, a zwłaszcza w rodzinie, odwiecznych zasad moralnych"4. Hierarchia kościelna $\mathrm{z}$ uwagą śledziła działania nowych władz.

Dostrzegając spustoszenia moralne i materialne ostatnich lat, biskupi w jednym z pierwszych powojennych listów pytali: „Jak wygląda duchowe oblicze świata po potopie? Czy narody wysnuły właściwe wnioski z moralnej

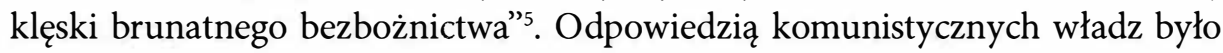

${ }^{1}$ Cyt. za: J. Wolny, Ostatnie lata działalności kościelnej Adama Stefana Sapiehy, Księga Sapieżyńska,

t. 2, Kraków 1986, s. 510.

${ }^{2}$ Tamże.

${ }^{3}$ Tamże, s. 514.

${ }^{4}$ Tamże.

${ }^{5}$ Kościół katolicki w Polsce wobec zagadnień chwili. Przemówienie Księdza Kardynała Augusta Hlonda, Prymasa Polski, na akademii ku czci Chrystusa Króla w Poznaniu, w: List y Pasterskie Episkopatu Polski 1945-1974, Paris 1975, s. 13 (dalej skrót: LPEP 1945-1974). 
ogłoszenie nowego, laickiego prawa małżeńskiego: „W świetle zasad katolickich Episkopat rozpatrzył nowe prawo małżeńskie, ogłoszone dekretem z 25 września 1945 roku. Z bólem stwierdzamy, że duch prawa jest laicystyczny, niezgodny $\mathrm{z}$ chrześcijaństwem, przeciwny katolickim tradycjom kraju"6.

Zapowiedzi Bieruta, że jego rząd dąży do utrzymania dobrych stosunków z Kościołem nie wyszły poza sferę obietnic, gdyż rzeczywistość wyglądała inaczej. Władza stopniowo, ale konsekwentnie starała się oddzielić Kościół od społeczeństwa7. W dniu 19 stycznia 1947 r. odbyły się pierwsze w powojennej Polsce wybory do Sejmu Ustawodawczego, którego głównym zadaniem miało być przygotowanie nowej konstytucji. Władze zabiegały o udział społeczeństwa w dyskusji o zasadach przyszłej ustawy konstytucyjnej. W dyskusji tej zabrali głos również biskupi polscy. Wstrząśnięci manipulacjami, terrorem i fałszerstwami, dokonanymi podczas styczniowych wyborów, biskupi wystosowali żądania, aby zagwarantowane $\mathrm{w}$ przyszłej konstytucji podstawowe prawa obywatelskie nie były w przyszłości deptane ${ }^{8}$.

W dniu 22 października 1948 r. zmarł kardynał August Hlond. Przed śmiercią przekazał Piusowi XII, za pośrednictwem swojego sekretarza ks. Antoniego Baraniaka, swoje życzenia co do nominacji następcy. Miał nim być biskup lubelski Stefan Wyszyński ${ }^{9}$ liczący 47 lat. Po objęciu stolicy S. Wyszyński podjął próbę przeprowadzenia Kościoła przez trudne lata zaplanowanej walki z religią. Przeciwstawiając się deprecjacji rodziny, przypominał rodzicom o ich prawach i obowiązkach względem swych dzieci, których żadna władza państwowa nie może negować: „Jesteście ludźmi! Rodzicie ludzi i macie prawo wychowywać ich po ludzku! Nie ma wychowania ludzkiego bez wychowania religijnego. Jesteście istotami rozumnymi! Macie prawo wychowywać swe dzieci według najlepszego zrozumienia. Jesteście istotami wolnymi! Do zasadniczych znamion wolności należy wolność oddziaływania na swoje dzieci zgodnie z rozumnym porządkiem rzeczy. Jesteście istotami miłującymi! Wolno przekazywać dzieciom to, co sami miłujecie i dbać o to, by inni tak czynili w Waszym imieniu"10.

${ }^{6}$ W sprawie małżeńskiej. Orędzie Episkopatu Polski, LPEP 1945-1974, s. 26.

${ }^{7}$ Por. P. Raina, Kościół w PRL. Dokumenty, t. 1, Poznań 1994, s. 69.

${ }^{8}$ Por. tamże.

${ }^{9}$ Stefan Wyszyński (1901-1981) święcenia kapłańskie przyjął w 1924 r.; ukończył wyższe studia na Wydziale Prawa Kanonicznego KUL (1925-1929), profesor w Wyższym Seminarium Duchownym we Włocławku (1931), redaktor „Ateneum Kapłańskiego” (1932-1939), członek Rady Społecznej przy Prymasie Polski (1937); konferencjonalista inteligencji katolickiej podczas okupacji i kapelan podczas Powstania Warszawskiego, biskup lubelski (1946-1948), arcybiskup gnieźnieński i warszawski (1948), kardynał (1953), Prymas Polski (1948-1981).

${ }^{10} \mathrm{~W}$ sprawie religijnego wychowania dzieci i młodzieży. List Pasterski Prymasa Polski, w: Listy Pasterskie Prymasa Polski 1946-1974, s. 208. 
Przeciwstawiając się zbrodniczemu prawu do zabijania nienarodzonych dzieci biskupi przypominali, że ocalenie poczętych dzieci leży przede wszystkim w rękach rodziców: „Pierwsze wezwanie zwracamy do rodziców chrześcijańskich, których Bóg powołał do zaszczytu przekazywania tego najwyższego w porządku natury daru Bożego - życia. Niech nie sprzeniewierzają się swemu powołaniu. Szczególne wezwanie zwracamy do matek, by uszanowały swą wysoką godność macierzyńską, by wzorem matki wszystkich żyjących ludzi - Ewy - były matkami żywych, a nie umarłych"11. Mówili też rodzicom o ich obowiązkach wychowawczych względem dzieci, szczególnie ważnych w sytuacji zaprogramowanej ateizacji: „Mówiąc o rodzinie, jeszcze jedną sprawę pragniemy poruszyć: wychowanie młodzieży. Nie tylko należy dać życie dziecku, ale również trzeba je wychować. Pod tym względem też źle się u nas dzieje. Przestępczość małoletnich: tylko kroniki milicyjne zanotowały w zeszłym roku przeszło 25000 młodocianych przestępców, a były wśród nich i rabunki, i nawet zabójstwa. Demoralizacja młodzieży, brak ideowości, pijaństwo, są to objawy wskazujące na pogarszający się stan moralny naszego społeczeństwa"12.

Rząd zaostrzył znacznie swoją politykę wobec Kościoła. Wydawał dekrety i rozporządzenia, ograniczając prawai wolność Kościoła. Przez odpowiednieustawy i zarządzenia Kościół zobowiązany był do płacenia podatków i prowadzenia ksiąg finansowych jak przedsiębiorstwa. Żądano od niego przekazania administracji państwowej parafialnych ksiąg metrykalnych. Zakazami administracyjnymi uniemożliwiono wiernym, zwłaszcza młodzieży, udział w uroczystościach religijnych. Członkom Episkopatu zarzucono współpracę z okupantem w czasie wojny i antynarodową działalność po wojnie ${ }^{13}$.

Dnia 9 lutego 1953 r. Rada Państwa uchwaliła dekret o „obsadzaniu duchownych stanowisk kościelnych”, który był jawnym pogwałceniem praw i niezależności organizacyjnej Kościoła. Wszystko wskazywało na to, że władzą najwyższą w hierarchii kościelnej nie będzie papież, lecz rząd polski. W tej sytuacji nie było już miejsca na jakiekolwiek ustępstwa ze strony Kościoła ${ }^{14}$. Episkopat Polski zebrał się 8 maja 1953 r. w Krakowie z okazji jubileuszu siedemsetlecia kanonizacji biskupa Stanisława Szczepanowskiego, który stracił życie broniąc praw Kościoła. I właśnie 8 maja biskupi polscy uchwalili słynny memoriał, który wszedł do historii jako memoriał „Non possumus”15.

${ }^{11}$ W obronie życia nienarodzonych. List Pasterski Episkopatu Polski, LPEP 1945-1974, s. 123.

${ }^{12}$ O rodzinie. List Pasterski Episkopatu Polski, LPEP 1945-1974, s. 160.

${ }^{13}$ Por. P. Raina, Kościót w PRL. Dokumenty, t. 1, dz. cyt., s. 139.

${ }^{14}$ Por. tamże, s. 379.

${ }^{15}$ Prymas S. Wyszyński tłumaczył znaczenie słów non possumus podczas procesji Bożego Ciała zebranym 4 czerwca przed kościołem św. Anny w Warszawie 200 tysiącom wiernych. Powiedział wtedy, że 
W nocy z 25 na 26 września 1953 r. Prymas Polski został aresztowany. Episkopat zwrócił się do rządu z prośbą, by Prymas Polski znalazł się nie w więzieniu, lecz zamieszkał w jednym z klasztorów, na co rząd wyraził zgodę. Prymasa umieszczono najpierw w klasztorze kapucynów w Rywałdzie, a potem przewieziono do Stoczka Warmińskiego. Losy Prymasa pozostały hierarchii kościelnej i społeczeństwu nieznane ${ }^{16}$.

Po aresztowaniu Prymasa Polski rząd kontynuował swoją antykościelną politykę. Nadal indagowano, przesłuchiwano i zastraszano duchowieństwo, proponowano księżom obejmowanie stanowisk kościelnych $\mathrm{z}$ pominięciem kandydatów Kurii, usuwano katechetów ze szkół, zamykano internaty kościelne, utrudniano duchownym dostęp do ubezpieczeń społecznych ${ }^{17}$.

Stawało się coraz bardziej jasnym, że religia przestanie być przedmiotem szkolnym. Ówczesne władze nie chciały pamiętać, że lekcje religii sięgają głęboko w podstawy wychowania i w tradycje polskiej szkoły: „Poglądy takie dyskwalifikują wartość nauki religii w oczach uczniów i w oczach społeczeństwa, kłócą się wreszcie z całą tradycją polskiej szkoły, która zawsze i stale uważała wychowanie religijne za pierwszy i najważniejszy obowiązek szkoły"18. Zamiast dotychczasowych zakładów, prowadzonych przez zakony, dzieci pozbawione rodziców miały być wychowane w duchu nie tylko obojętnym, lecz i antyreligijnym, w tak zwanym Domu Dziecka ${ }^{19}$.

Episkopat Polski wielokrotnie upominał się o poszanowanie praw Kościoła i rodziców katolickich do wychowania dzieci i młodzieży po katolicku: „Los więc nauki religii w szkołach spoczął w Waszych rękach. Od Was zależy, czy religia nadal będzie wykładana w naszych szkołach polskich, czy nie”20. „Do dzieci zaś z katolickich rodzin zwracamy się z gorącą prośbą, aby jeszcze bardziej pokochały naukę religii, chociaż nie jest ona przedmiotem nauki $\mathrm{w}$ szkole, $\mathrm{i}$ aby pilnie

tam, gdzie kapłaństwo jest w niewoli, nie ma wolności sumienia i wszelkie próbyuzależnienia kapłanów od władzy państwowej są zamachem na podstawowe wolności, wobec czego nie można pójść na żadne ustępstwa. I dodał, że biskup „musi bronić i bronić będzie - nawet do oddania własnej krwi - wolności kapłaństwa Chrystusowego". Por. P. Raina, Kościót w PRL. Dokumenty, t. 1, dz. cyt., s. 380.

${ }^{16}$ Por. tamże, s. 381.

${ }^{17}$ Por. tamże, s. 455.

${ }^{18}$ Por. tamże, s. 36.

${ }^{19}$ Por. tamże, s. 37.

${ }^{20}$ Do rodziców katolickich. Orędzie Episkopatu Polski, LPEP 1945-1974, s. 179; „Do Was zaś, Rodzice katoliccy, którzy przez sakrament Chrztu świętego i Bierzmowania staliście się prawdziwymi wyznawcami Chrystusa, zwracamy się z gorącą prośbą, abyście w pełnym zrozumieniu swych naturalnych i obywatelskich uprawnień, a równocześnie swych katolickich obowiązków, pomagali nam w tym podstawowym zadaniu nauczania religijnego. Czyńcie to w taki sposób, jak zawsze czynili rodzice chrześcijańscy, ojcowie i matki. Wszyscy wspólnie jesteśmy odpowiedzialni za bezcenny skarb wiary". O nauczaniu prawd wiary świętej. List Pasterski Biskupów Polskich do rodziców, dzieci i młodzieży katolickiej, LPEP 1945-1974, s. 234. 
uczestniczyły w katechizacjach kościelnych. Boga musicie szukać i poznawać w wielkim trudzie. Chrystus już nie ma wstępu do swoich ochrzczonych dzieci w szkole. Pobiegniecie więc tam, gdzie można go znaleźć"21.

Wbrew uzasadnionym nadziejom państwowe programy wychowania młodzieży szły po linii wręcz przeciwnej: „Wychowanie materialistyczne jest w swych założeniach wrogie etyce chrześcijańskiej i nauce Kościoła katolickiego. Praktyka wychowawcza, w duchu materialistycznym, potwierdza tę wrogość i ją potęguje. Uznawana jest inicjatywa prywatna wychowania materialistycznego; co więcej, jest ona popierana i utrzymywana przez państwo (Towarzystwo Przyjaciół Dziecka; prawidłowa nazwa Towarzystwo Przyjaciół Dzieci). Natomiast katolicka inicjatywa prywatna wychowania religijnego jest tępiona i niweczona"22.

Młodzież katolicka była przymuszana do wstępowania w szeregi ZMP, organizacji głoszącej światopogląd materialistyczny, a w praktyce antychrześcijański ${ }^{23}$. W teorii szkoły TPD (Towarzystwo Przyjaciół Dzieci) miały służyć młodzieży, której rodzice nie życzą sobie, żeby ich dzieci uczyły się religii - a nawet w Porozumieniu p. 10 e) mówił: „W razie tworzenia lub przekształcania szkoły zwykłej na szkołę bez nauki religii, rodzice katoliccy, którzy będą sobie tego życzyli, będą mieli prawo i możność posyłania dzieci do szkół z nauczaniem religii" ${ }^{24}$. Przeprowadzano też programową laicyzację przedszkoli i świetlic: „Posuwa się ona tak daleko, że dzieciom katolickim zabrania się modlitwy i uczęszczania w niedziele do Kościoła. Przedszkola parafialne i caritasowe są zamykane, chociaż bardzo często odznaczają się świetną organizacją"25.

Biskupi polscy zaznaczali, iż „Nigdy Lud Boży w Polsce nie był przedmiotem tak dalece zorganizowanej akcji ateistycznej i laicystycznej jak za dni naszych. Powołano szereg instytucji, wśród nich Stowarzyszenie Ateistów i Wolnomyślicieli (SAiW) oraz Towarzystwo Szkoły Świeckiej (TSŚ)"”26. Napisana na zlecenie J. Stalina nowa konstytucja nie pozostawiała żadnych wątpliwości co

${ }^{21}$ Tamże, s. 235; „Zwracamy się do Was po to, byście dalej swoją postawą wspierali Kościół w tej pracy, przysyłając jak najliczniej dzieci i młodzież na godziny religijne". Do rodziców katolickich. Odezwa Biskupów Polskich, LPEP 1945-1974, s. 316; „Prawa Kościoła do wychowania religijnego i nauczania prawd wiary są pochodzenia Bożego. Mają zatem pozycję nadrzędną w stosunku do wszystkich praw ludzkich, także państwowych, i nie mogą być przez nie ani ograniczane, ani nadzorowane". O prawie do nauczania religii. Orędzie Biskupów Polskich do kapłanów i wiernych, LPEP 1945-1974, s. 318.

${ }^{22}$ P. Raina, Kościót w PRL. Dokumenty, t. 1, dz. cyt., s. 160.

${ }^{23}$ Por. tamże, s. 315.

${ }^{24}$ Tamże, s. 315-316.

${ }^{25}$ Tamże, s. 161.

${ }^{26}$ O moralnym zagrożeniu narodu. List Episkopatu Polski do duchowieństwa, LPEP 1945-1974, s. 505. 
do stosunku władz państwowych do Kościoła i ludzi wierzących. Konstytucja sprzeciwiła się wyraźnie jakiemukolwiek rodzajowi religijnego wychowania.

Szybko jednak okazało się, że otwarta walka z Kościołem może skończyć się klęską państwa. Już na III Plenum KC PZPR w styczniu 1955 r. sekretarz KC Jerzy Morawski przyznał, że w kraju rządziło bezprawie, z „goryczą, piekącym bólem i wstydem - mówił - dowiedzieliśmy się o faktach brutalnego naruszania zasad praworządności ludowej”27. W jaskrawym przeciwieństwie do wypowiadanej oficjalnie krytyki łamania praworządności i nadużywaniu władzy stała konsekwentnie antykościelna polityka władz, opierająca się właśnie na łamaniu praworządności i nadużywaniu władzy. Dowodzą tego posunięcia władz wobec Kościoła w 1955 r.: stała ingerencja w nauczanie religii w salach parafialnych, przetrzymywanie w więzieniach kapłanów i członków zgromadzeń zakonnych, zajmowanie internatów prowadzonych przez zakony, odbieranie budynków kościelnych na ziemiach zachodnich, odmawianie zezwoleń na opiekę duszpasterską $\mathrm{w}$ więzieniach, usuwanie „nielojalnych” proboszczów z ich stanowisk ${ }^{28}$.

Nagła śmierć Bieruta dała początek procesowi liberalizacji życia w Polsce. Przełom w stosunkach Kościół - Państwo nastąpił dopiero po objęciu kierownictwa partii przez Władysława Gomółkę w październiku 1956 roku. Jednym z pierwszych kroków W. Gomółki, rozpoczynających proces demokratyzacji, była decyzja o zwolnieniu Prymasa Polski. 28 października 1956 roku Prymas Polski powrócił do Warszawy i objął urzędowanie ${ }^{29}$. Znamienna była jednak wciąż polityka dwulicowości, prowadzona przez kierownictwo partii wobec Kościoła. W osobistych rozmowach $\mathrm{z}$ dostojnikami kościelnymi dawano do zrozumienia, że przywiązuje się dużą wagę do stosunków z Kościołem, ale $\mathrm{w}$ rzeczywistości wszystkie działania skierowane były przeciwko niemu ${ }^{30}$. Nadzieje Kościoła na poprawę stosunków z państwem, czego zapowiedzią był październik 1956 r., okazały się złudne. Zupełnym zaskoczeniem był jednak dla Kościoła skierowany przeciwko niemu atak W. Gomółki na III Zjeździe

${ }^{27}$ „Nowe Drogi” 2 (1955), s. 10.

${ }^{28}$ Por. P. Raina, Kościót w PRL. Dokumenty, t. 1, dz. cyt., s. 483.

${ }^{29}$ Por. tamże, s. 537.

${ }^{30}$ Zob. Dokąd zmierza kierownictwo Kościoła?, „Argumenty” 15 III 1958, s. 1-3; W prasie krajowej nasilały się ataki na Kościół. W paszkwilach wyróżniało się szczególnie pismo „Argumenty”, gdzie duchowieństwo występowało jako „klerykalna konserwa”. Prześladowania i dyskryminacja wierzących były na porządku dziennym. Nie zezwalano na budowę kościołów, utrudniana była działalność charytatywna Kościoła. Nie pozwalano na przykład rozdzielać darów, które Kościół otrzymywał z zagranicy. O rzeczywistych zamiarach władzy dowiedzieć się można z poufnych wskazówek udzielonych przez Komitet Centralny niższym szczeblom partyjnym w liście do egzekutyw partyjnych z lipca 1958 r. Por. P. Raina, Kościół w PRL. Dokumenty, t. 1, dz. cyt., s. 611 i 635-647. 
PZPR, w marcu 1959 r. Partia, mówił W. Gomółka, nie może się pogodzić z jakąkolwiek reakcyjną działalnością polityczną ze strony Kościoła ${ }^{31}$. Kolejne lata PRL-u były konsekwentną realizacją próby odsunięcia Kościoła od wpływu na społeczeństwo, a szczególnie na proces wychowawczy młodych pokoleń.

\section{Kościół tarnowski}

II wojna światowa przyniosła też niepowetowane straty diecezji tarnowskiej, która znalazła się na terenie Generalnej Guberni, gdzie nie stosowano bezpośredniej germanizacji, ale posłużono się innymi metodami wykorzystania okupowanego terenu ${ }^{32}$. $\mathrm{Z}$ tego obszaru miała się bowiem rekrutować tania siła robocza dla niemieckiego przemysłu i rolnictwa. Władze okupacyjne traktowały Kościół w zależności od usług, jakie mógł oddać w realizacji tych planów. Przy tolerowaniu kultu religijnego, usuwano wszelkie akcenty patriotyczne z katechizacji ${ }^{33}$. Wzmożonej inwigilacji podlegało pozostawione Polakom szkolnictwo podstawowe i nauczanie religii. Warto też zaznaczyć, że w czasie okupacji ukazała się w Tarnowie niewielka publikacja, zawierająca krótki katechizm oraz zasady przygotowania dzieci do I Komunii świętej ${ }^{34}$. W wyniku wojny diecezja tarnowska poniosła wprawdzie dotkliwe straty personalne ${ }^{35}$ i materialne, ale okupantowi nie udało się włączyć skutecznie jej potencjału ludzkiego do swoich planów. Okres ten pozostawił jednak negatywne ślady w postawach religijno-moralnych ludzi. Życie ludzkie stało się towarem, którym handlowano, wzmógł się alkoholizm, a wielką plagą stały się kradzieże.

Czas PRL-u na terenie diecezji tarnowskiej niewiele różnił się od ogólnej sytuacji w kraju. Kościół tarnowski, na czele którego stał biskup Jan Stepa,

\footnotetext{
${ }^{31}$ Por. tamże, s. 661.

${ }^{32}$ Por. Z. Zieliński, Religia w narodowo-socjalistycznej koncepcji społeczeństwa, „Chrześcijanin w Świecie" 7-8 (1980), s. 24.

${ }^{33} \mathrm{Niemcy}$, wiedząc że katecheza podtrzymywała tradycje patriotyczne w zaborze austriackim, w sposób szczególny objęli represjami nauczanie religii.

${ }^{34}$ Zob. W. Dudziak, Pouczenie o pierwszej Spowiedzi św., Tarnów 1944.

${ }^{35}$ Por. B. Kumor, Diecezja tarnowska, w: Życie religijne w Polsce pod okupacją hitlerowska 1939-1945, Z. Zieliński (red.), Warszawa 1982, s. 257. Liczba represjonowanych księży i alumnów terrorem hitlerowskim w formie uwięzienia wynosiła 102. Liczba zamordowanych kapłanów, łącznie $\mathrm{z}$ rektorem seminarium duchownego, ks. inf. R. Sitką, wynosiła $27, \mathrm{z}$ czego 16 zginęło w obozach koncentracyjnych w Oświęcimiu, Dachau i innych, 6 rozstrzelano na miejscu, a 4 zginęło w więzieniach i w walce z wrogiem. 15 kapłanów i 3 alumnów doczekało się zwolnienia z obozu w Dachau w dniu 5 maja 1945 r. Największe nasilenie terroru hitlerowskiego przypadło na lata: 1941, kiedy uwięziono 57 kapłanów oraz 1939 - 17 kapłanów. Jeszcze w 1944 r. przebywało w więzieniach hitlerowskich 31 kapłanów, a w roczniku diecezjalnym notowano ich jako czasowo nieobecnych w diecezji.
} 
zmuszony był do przeciwdziałania zamierzonej ateizacji mieszkającej tu ludności. Narażona była ona na wszystkie negatywne działania władz państwowych. Nieuchronnym zjawiskiem stały się też przeobrażenia społeczno-socjologiczne mieszkającej tu ludności, co wpłynęło na zmianę dotychczasowego typu religijności. W latach 50 . XX w. zaczął on zmieniać się przede wszystkim pod wpływem postępującej urbanizacji i uprzemysłowienia terenu diecezji tarnowskiej. Migracja ludności ze wsi do miast, dojazdy do pracy, docieranie na wieś konkurencyjnych wartości za pomocą środków społecznego przekazu, coraz większa niezależność dorosłych dzieci od rodziców doprowadziły do osłabnięcia tradycyjnej religijności wiejskiej. Na terenie diecezji tarnowskiej proces ten następował z wyraźnym opóźnieniem. Do ostatnich lat nie zmienił się właściwie wybitnie rolniczy charakter tego terenu. Wciąż występował jeszcze powszechnie tradycyjny typ religijności ${ }^{36}$. Z upływem czasu narastał jednak oczywiście proces laicyzacjii ${ }^{37}$. Pojawiła się religijność selektywna, odchodzenie od praktyk niedzielnych, zmniejszyła sięakceptacja prawd religijnych i przykazań Bożych ${ }^{38}$. Wydaje się jednak, że te zmiany należy interpretować w kategoriach powszechnego procesu laicyzacji, a nie $\mathrm{w}$ kategoriach negacji katolicyzmu $\mathrm{w}$ diecezji tarnowskiej ${ }^{39}$. Trzeba pamiętać, że procesy przemian religijnych, podobnie jak przemian kulturowych, mają charakter długofalowy i dlatego chwilowe wahania wskaźników statystycznych nie zawsze mają znaczenie dla ogólnych trendów rozwojowych ${ }^{40}$.

Czytelnym znakiem właściwego kierunku w duszpasterstwie była systematycznie wzrastająca liczba powołań kapłańskich i zakonnych w diecezji tarnowskiej ${ }^{41}$. Ten fenomen licznych powołań odnotowała również Stolica

${ }^{36}$ Por. J. Majka, Jaki jest katolicyzm polski?, w: Socjologia religii, F. Adamski (red.), Kraków 1983, s. $258-274$.

${ }^{37}$ Por. K. Święs, Wartości religijno-moralne młodzieży na przykładzie wybranych szkót diecezji tarnowskiej. Studium socjologiczne, Lublin 1994, s. 224.

${ }^{38}$ Por. J. Styrna, Przemiany religijnej funkcji rodziny w środowisku wiejskim, Lublin 1973, s. 115; zob. także: M. Grzanka, Wartości religijno-moralne młodzieży robotniczej $w$ Niedomicach. Studium socjologiczne, Lublin 1991.

${ }^{39} \mathrm{~W}$ świetle badań socjologicznych z 1985 r. województwo nowosądeckie, należące do diecezji tarnowskiej, posiadało najwyższy wskaźnik wiernych praktykujących w Polsce, to jest około $50 \%$, przy średniej krajowej 18,1\%, w: Kościót katolicki w Polsce 1918-1990. Rocznik statystyczny, L. Adamczuk, W. Zdaniewicz (red.), Warszawa 1991, s. 187.

${ }^{40}$ Por. J. Majka, Historyczno-kulturowe uwarunkowania katolicyzmu polskiego, w: Socjologia religii, F. Adamski (red.), Kraków 1983, s. 257.

${ }^{41}$ Według zestawienia statystycznego, obejmującego księży diecezjalnych co do miejsca urodzenia z 1985 r., diecezja tarnowska była zdecydowanie na pierwszym miejscu wśród wszystkich diecezji polskich z liczbą 1563 księży, w: Kościót katolicki w Polsce 1918-1990. Rocznik statystyczny, L. Adamczuk, W. Zdaniewicz (red.), Warszawa 1991, s. 409; zob. także: Sylwetki matek kapłanów, Z. Walkiewicz (red.), Poznań - Warszawa 1981. 
Apostolska. Papież Paweł VI pisał o wielkiej rzeszy kapłanów diecezjalnych i zakonnych, którzy wyszli $\mathrm{z}$ diecezji tarnowskiej i pracują $\mathrm{w}$ duszpasterstwie niemal na całym świecie ${ }^{42}$. Należy również zauważyć, że stan duchowy diecezji nie był jedynie wynikiem zbiegu okoliczności historyczno-socjologicznych. Został on wypracowany w wyniku zaplanowanego i ofiarnego wysiłku duszpasterskiego. W równej mierze dotyczył on kultury duchowej, jak i inspiracji w kulturze materialnej społeczeństwa. Dzięki takiemu oddziaływaniu katolicyzm diecezji tarnowskiej można by określić jako „katolicyzm katechizmowy”43. Oznaczało to, że ludność cechowała katechizmowa znajomość prawd wiary i wypełnianie nakazanych (katechizmowych) praktyk religijnych. Nadto, że ówczesny katolicyzm w tarnowskim Kościele partykularnym osiągnięto dzięki systematycznemu katechizowaniu poza szkołą i z ambon, gdzie często głoszono kazania katechizmowe ${ }^{44}$.

Biskup Jerzy Ablewicz - następca biskupa Jana Stepy - inaugurując działalność duszpasterską w diecezji tarnowskiej, miał żywo w pamięci słowa wypowiedziane przez arcybiskupa Eugeniusza Baziaka podczas uroczystości jego konsekracji w Przemyślu: „Masz objąć władztwo dusz diecezji wielkiej. Masz przewodniczyć kapłanom tej diecezji, znanym w całej Polsce ze swej karności, swojej gorliwości, znanej także $\mathrm{z}$ wielkich rezultatów, metod pracy duszpasterskiej, stosowanych $\mathrm{w}$ tej diecezji. Masz także przewodzić wiernym, wiernym bardzo przywiązanym do Kościoła katolickiego, wiernym, którzy odznaczają się wielką pobożnością i wielkim przywiązaniem do swoich kapłanów i swoich biskupów" ${ }^{\text {45 }}$. Autentyczność takiej oceny potwierdził biskup łódzki, który przesyłając gratulacje jednocześnie też informował: „Ksiądz biskup obejmuje diecezję przodującą pod względem duszpasterskim"46. Ta świadomość towarzyszyła biskupowi J. Ablewiczowi przez cały okres jego pasterzowania. Zabiegał też o dokładne poznanie regionu, obyczajowości, religijności, struktury społecznej i zawodowej ludności diecezji, która w swojej historii

${ }^{42}$ Por. B. Kumor, Biskupi tarnowscy i ich formacja religijno-moralna diecezji, „Currenda” 1-3 (1988), s. 63; zob. Podziękowanie Kongregacji Wychowania Katolickiego za sprawozdanie z działalności Wyższego Seminarium Duchownego w Tarnowie, „Currenda” 1-3 (1989), s. 8-9; „Alma Mater Tarnoviensis”. Ksiegga pamiątkowa $z$ okazji 150 rocznicy założenia Instytutu Teologicznego i Seminarium Duchownego w Tarnowie 1821-1971, P. Bednarczyk, F. Gawlik (red.), Tarnów 1972.

${ }^{43}$ Por. K. Święs, Wartości religijno-moralne młodzieży na przykładzie wybranych szkót diecezji tarnowskiej, dz. cyt., s. 224.

${ }^{44}$ Por. J. Majka, Jaki jest katolicyzm polski?, dz. cyt., s. 274.

${ }^{45}$ Przemówienie J. E. Ks. Arcybiskupa Metropolity Eugeniusza Baziaka, „Currenda" 4-6 (1962), s. 105.

${ }^{46}$ List gratulacyjny biskupa Michała Klepacza do nowego biskupa tarnowskiego Jerzego Ablewicza, „Currenda" 4-6 (1962), s. 132. 
„była wystawiana na wielkie wstrząsy gospodarcze, społeczne, polityczne. Można by powiedzieć, że była to diecezja $\mathrm{z}$ dużym temperamentem społeczno-politycznym"47. Przewidywałbowiem, że bez tej wiedzy skuteczność działalności duszpasterskiej będzie nieproporcjonalna do wykonanej pracy. Dlatego często podkreślał: „Każda diecezja urzeczywistnia jeden, święty, katolicki i apostolski Kościół w swoich własnych specyficznych warunkach społecznych, kulturowych, gospodarczych, politycznych. Każda diecezja jest inna, każda ma swoją specyfikę, dlatego nazywamy ją Kościołem partykularnym"48. Wrażliwy na przeszłość i zatroskany o przyszłość powierzonej sobie diecezji tarnowskiej tworzył jej teraźniejszość poprzez skuteczne inicjatywy duszpasterskie i katechetyczne ${ }^{49}$.

${ }^{47}$ J. Ablewicz, Dziękczynienie i odpowiedzialność za nasze diecezjalne dziedzictwo, „Tarnowskie Studia Teologiczne" (1986), cz. 1, s. 8.

${ }^{48}$ Przemówienie biskupa Jerzego Ablewicza na rozpoczęcie pierwszej zwyczajnej sesji plenarnej IV Synodu Diecezji Tarnowskiej w bazylice katedralnej w Tarnowie 14 czerwca 1983 roku, w: IV Synod Diecezï Tarnowskiej, P. Gajda, A. Kmiecik, A. Kokoszka, A. Paciorek (red.), Tarnów 1990, s. 12.

${ }^{49}$ Por. M. Zając, Katechizacja $w$ diecezji tarnowskiej w okresie posługi biskupiej Jerzego Ablewicza (1962-1990), Lublin 1996, s. 39-40. 